\title{
Pesquisa educacional com base nas artes: pensando a educação dos professores como experiência estética*
}

João A. Telles

Universidade Estadual Paulista

\author{
Correspondência: \\ João A. Telles \\ UNESP - Faculdade de Ciências e \\ Letras de Assis \\ Departamento de Educação \\ Av. Dom Antonio, 2100 \\ 19806-900 - Assis - SP \\ e-mail: jtelles@assis.unesp.br
}

\footnotetext{
* Este artigo é resultado do projeto Teatro e reflexão crítica compartilhada entre professores: dois dispositivos de agenciamento de parcerias entre universidades e escolas, financiado pela FAPESP - Fundação de Amparo à Pesquisa do Estado de São Paulo por meio de uma bolsa de pósdoutoramento (Processo: 2002/ 07562-0) na Universidade Charlesde-Gaulle, Lille III, França.
}

\section{Resumo}

Neste artigo, o autor descreve dois estudos, realizados com professores, nos quais objetos de arte são usados como dispositivos deflagradores de reflexão compartilhada. Teoricamente fundamentado em uma nova modalidade de investigação qualitativa no campo da Educação - a Pesquisa Educacional com Base nas Artes $(P E B A)$-, ele discute particularidades do funcionamento e do papel dessa modalidade de pesquisa no desenvolvimento profissional docente, as diferentes naturezas dos dois objetos de arte utilizados (a fotografia e o espetáculo teatral) e aponta para duas principais vertentes dessa modalidade de pesquisa - a vertente de produção de significados, pela qual o educador de professores e os participantes da pesquisa compartilham e constroem significados ao entrarem em contato com um objeto de arte previamente pronto e confeccionado por um artista profissional; e a vertente representacional, pela qual os professores e educadores participantes constroem, individualmente ou de forma compartilhada, um determinado objeto de arte que reflita e expresse suas representações do mundo da docência. Por fim, o artigo sugere que a PEBA, além de estabelecer contextos reflexivos nos quais alunos e professores têm oportunidades de desvelar a experiência estética, instaura relações alternativas dos participantes com o conhecimento e com a prática pedagógica, evidenciando sua importância social e suas forças revitalizadoras.

\section{Palavras-chave}

Educação de professores - Reflexão - Pesquisa com base nas artes - Experiência estética. 


\section{Arts-based educational research: thinking teacher education as an aesthetic experience}

João A. Telles

Universidade Estadual Paulista

Contact:

João A. Telles

UNESP - Faculdade de Ciências e

Letras de Assis

Departamento de Educação

Av. Dom Antonio, 2100

19806-900-Assis - SP

e-mail: jtelles@assis.unesp.br

\footnotetext{
* This article results from the project Theatre and Shared Critical Reflection among Teachers: Two agency devices for partnerships between universities and schools, which was funded by FAPESP - Research Support Agency of the State of São Paulo through a postdoctoral scholarship (Process: 2002) 07562-0) at the Université Charlesde-Gaulle, Lille III, France.
}

\begin{abstract}
The author describes in this article two studies conducted with teachers, in which art objects are used as devices to trigger shared reflection. Theoretically grounded in a novel modality of qualitative investigation in the field of Education - Arts-based Educational Research (ABER), the text discusses peculiarities of the working and role of this research mode in teacher professional development, the different natures of the two art objects employed (photography and theater), and points to the two main tendencies within this research mode - the tendency of meaning production, in which the teacher educator and the participants in the research share and build meanings by coming in contact with an art object previously prepared by a professional artist; and the representationist tendency, in which participating teachers and educators construct, individually or in shared fashion, a certain art object that reflects and expresses their representations of the world of teaching. Lastly, the article suggests that ABER, apart from establishing contexts of reflection in which students and teachers have the opportunity to unfold the aesthetic experience, institutes alternative relationships of the participants with the pedagogical knowledge and practice, revealing its social import and its renewing force.
\end{abstract}

\section{Keywords}

Teacher education - Reflection - Arts-based research - Aesthetic experience. 
0 objetivo deste artigo é explorar os múltiplos modos como objetos de arte, tais como a fotografia e o espetáculo teatral, podem funcionar como dispositivos deflagradores de reflexão compartilhada entre professores. $\mathrm{Na}$ primeira parte do artigo, apresento algumas considerações teóricas acerca de uma nova modalidade de investigação qualitativa no campo da Educação - a Pesquisa Educacional com Base nas Artes $^{1}$ (PEBA) -, descrevendo o modo como a fotografia e o espetáculo teatral podem funcionar como deflagradores desse tipo de reflexão entre grupos de professores. Em seguida, discuto algumas particularidades acerca do funcionamento dessa modalidade de pesquisa e o seu papel em dois estudos que realizei com professores franceses e brasileiros. Nessa oportunidade, exploro as diferentes naturezas dos dois objetos de arte que utilizei como deflagradores de reflexão e aponto para duas principais vertentes dessa modalidade de pesquisa: a vertente de produção de significados, pela qual os participantes da pesquisa compartilham e constroem significados ao entrarem em contato com um objeto de arte previamente pronto e confeccionado por um artista; e a vertente representacional, pela qual os professores e educadores participantes constroem, individualmente ou de forma compartilhada, um determinado objeto de arte que reflita e expresse suas representações do mundo da docência.

$\mathrm{Na}$ segunda parte do artigo, aponto e discuto algumas especificidades das reflexões compartilhadas que foram realizadas por meio da PEBA. Nessa parte, aponto para algumas possibilidades de elas oferecerem oportunidades de concretização da experiência estética proporcionada pelos dois objetos de arte aqui utilizados. Nessa mesma parte, ainda discuto esse tipo de pesquisa como forma de estabelecer contextos reflexivos que propiciem oportunidades aos alunos e professores para o desenvolvimento de experiências estéticas.

Concluo o artigo com uma breve discussão acerca do funcionamento da PEBA e o seu relacionamento com o desenvolvimento do professor, mostrando que essa modalidade de pesquisa qualitativa entre docentes pode instaurar uma outra relação do professor com o conhecimento e com a prática pedagógica. Por meio dessa nova relação do professor com o conhecimento e das perspectivas representacionais e de revisitação da vida nas escolas que a PEBA oferece, desejo mostrar a importância social e a força revitalizadora dessa modalidade de pesquisa.

\section{A pesquisa com base nas artes em Educação}

Embora o trabalho dos artistas seja sempre considerado da perspectiva ampla da criatividade, vários artistas contemporâneos se empenham na realização de formas altamente sistemáticas e profundas de pesquisa... Ao prepararem um espetáculo teatral, por exemplo, diretores, dramaturgos e atores freqüentemente realizam uma ampla investigação da linguagem e dos costumes daquele período ou mesmo a história das produções daquele determinado trabalho. Artistas visuais podem investigar a química e durabilidade de determinados materiais ou investigar processos perceptuais... Compositores e artistas performáticos [coreógrafos e bailarinos, por exemplo] pesquisam nas bibliotecas, coletam histórias orais e se empenham em estudos etnográficos sem dar nomes ao que fazem (Sabatini, 1993; Barone, 1995).

0 pioneiro a reivindicar o potencial das Artes para buscar instrumentos e formas alternativas de representação dos achados das pesquisas em Educação foi Elliot W. Eisner em seu livro The enlightened eye (1991). Para esse educador de professores, as Artes têm uma longa tradição em descrever, interpretar e avaliar o mundo e dar forma à experiência. A proposta de Eisner de utilizar as Artes para melhor compreender as escolas e as salas de aula é ousada, já que, como afirma o autor, o que tem limitado as universidades e os acadêmicos de verem tal potencial é a

1. Arts-Based Educational Research (Eisner, 1991, 1997; Diamond; Mullen, 1999; Telles, 2005), Arts-informed Research ou Arts-Based Approaches to Qualitative Inquiry (Gray, 2003). 
concepção limitada e limitante do que seja conhecimento e do que seja saber (Eisner, 1991).

Pluralismo metodológico e holismo organizacional são os pilares que sustentam o trabalho desse autor. 0 primeiro diz respeito à utilização de métodos diversos e múltiplos instrumentos de representação apropriados ao objeto de estudo (neste artigo, a fotografia e o espetáculo teatral); o segundo diz respeito à atenção dada pelo pesquisador à mescla dos fatores interagentes e interdependentes dos fenômenos no campo da Educação: "o que os professores e alunos fazem é influenciado por suas localizações dentro de um sistema" (1991, p. 2).

Outro arte-educador que traça associações fortes entre as Artes e a pesquisa é Richard Courtney (1987). Já nos anos 1980, esse autor faz referência aos modos alternativos de representação do conhecimento obtido por meio da pesquisa que são oferecidos pelas Artes. Courtney assevera que:

[...] os artistas fazem pesquisas enquanto criam, em um sentido popular, isto é verdade. Os artistas descobrem novas maneiras de aprender, usam métodos inovadores para explorar o significado e estão no limiar do futuro. Eles se concentram em processos mentais de imaginação, vêem possibilidades e, então, as expressam por meio da ação - via um meio artístico durante suas experiências de vida. Isto significa que os artistas se empenham na pesquisa acerca das experiências. [...] 0 que faz com que os artistas sejam diferentes é o meio pelo qual realizam [e representam os achados de] suas investigações a Arte. (1987, p. 1)

Partindo dos trabalhos de Eisner (1991), outros pesquisadores da Educação têm implementado suas idéias iniciais. Sarason (1999), por exemplo, introduz a idéia de ensinar como arte performática. Outros educadores de professores enfocam as metáforas utilizadas pelos professores como representações de suas experiências e seus conhecimentos². Diamond e Mullen (1999) introduzem novas formas de representação, tais como o texto-dividido (split text) e palimpsestos - textos nos quais são apresentadas, simultaneamente, as histórias dos participantes da pesquisa e, às margens ou em rodapé, os textos do pesquisador comentando as histórias dos participantes. Barone (1995), por sua vez, introduz a narrativa ficcional para dar acesso aos seus professores-leitores a experiência vicária por meio das artes. Eis como Denzin explica tal experiência:

Exemplos de experiências vicárias são encontrados nas artes. Por meio da forma artística de pesquisa conhecida como narrativas de histórias educacionais, o leitor pode experienciar, de forma vicária, um mundo virtual crível da escola ou sala de aula, habitado por pessoas que são as personagens virtuais da história. Este tipo de experiência estética pode ser suficientemente significativa a ponto de causar um questionamento das premissas fundamentais dos valores, assim como das bases ideológicas sobre as quais as decisões relativas à educação são tomadas. (1992, p. 15)

No Brasil, a PEBA na educação dos nossos professores é ainda incipiente. Em publicações anteriores (Telles, 1997; 1998a; 1998b; 1998c; 1999; 2000), tentei concretizar uma nova forma de representar o conhecimento obtido por meio de minhas pesquisas na área de desenvolvimento do professor de línguas estrangeiras, utilizando metáforas, narrativas e a videobiografia - um gênero de escrita autobiográfica por meio de imagens, músicas e narrativas das vidas de minhas participantes. Damianovic (1998) utiliza textos autobiográficos, poesia e fotografia para representar o seu desenvolvimento e processo reflexivo como professora. Melo (1999), Pires (1998), Motta (1997) e Dias (2001) utilizaram narrativa de vida, metáforas e imagens para representar seus próprios processos reflexivos e construir contextos para a reflexão de suas professoras-participantes.

Na próxima sessão, aprofundo minhas observações acerca das características, do fun-

2. Ver Lakoff; Johnson (1980); Munby (1986); Carroll (1994); Bullough; Stokes (1994); Telles (1997; 1999; 2005). 
cionamento e do papel dessa modalidade de pesquisa qualitativa na área de desenvolvimento profissional de professores e ilustro sua operacionalização no contexto da reflexão por meio de objetos de arte.

\section{PEBA: seu funcionamento e o seu papel em dois estudos sobre reflexão compartilhada}

Não defendo a substituição das formas tradicionais de pesquisa qualitativa por música, pintura ou filmes nem digo que a pesquisa com base nas artes é, de algum modo, melhor do que a pesquisa qualitativa tradicional. Meu argumento está fundamentado no pressuposto de que idéias educacionais diferentes requerem diferentes formas de representação para que sejam efetivamente comunicadas e que deveríamos começar experimentando outras formas de representação além da literatura. (Fordon, 2005, p. 07, minha tradução) ${ }^{3}$

Já que a PEBA tem como princípio buscar formas alternativas de representação do conhecimento construído pela pesquisa ${ }^{4}$, o que dela se destaca nessa busca diz respeito aos modos de representação, como mostra a epígrafe acima. Assim, ressalto, abaixo, os aspectos e os potenciais semióticos dessa modalidade de pesquisa em uma ação didática de formação de professores centrada na reflexão compartilhada, como foram os casos dos dois estudos realizados - um utilizando a fotografia e o outro, o espetáculo teatral como deflagradores de reflexão.

De início, quanto às suas naturezas, os dois objetos de arte que foram utilizados neste estudo são distintos. A fotografia proporciona e significa a experiência humana por meio das imagens escolhidas pelo fotógrafo. 0 espetáculo teatral, por sua vez, proporciona e significa essa experiência humana por meio de um emaranhado de signos que se coalescem nesse processo de significação: voz, figurinos, movimentos, músicas, personagens nele contidos, textos por eles enunciados, iluminação das cenas, dentre outros sistemas sígnicos que foram por mim escolhidos na compo- sição do espetáculo teatral para representar as questões pensadas durante o processo de pesquisa realizado com os alunos de um curso de Letras de uma universidade estatal. No trabalho de fotografias com professores franceses, utilizei somente as representações já prontas e trazidas por meio das imagens fotográficas de crianças em escolas, oferecidas pelo fotógrafo Robert Doisneau em seu álbum Les doigts pleins d'encre ${ }^{5}$ (1989). A pesquisa sobre as escolas e as representações de seus resultados por meio das fotografias foi, portanto, realizada por Doisneau e não por mim. 0 que fiz foi utilizar as representações dos resultados da pesquisa desse fotógrafo (29 fotografias selecionadas de seu álbum) nas escolas francesas para deflagrar reflexão entre os professores participantes. Já no estudo brasileiro, eu e os alunos do curso de Letras que participaram do estudo tivemos que 'construir' o objeto de arte. Primeiramente, eles representaram suas experiências e o nosso processo de pesquisa acerca dos PCNs montando uma peça teatral (diferentemente das fotografias, que já vieram prontas). Em seguida, submeteram suas representações contidas na peça teatral aos professores, educadores, pais e alunos que compunham as platéias. Desse modo, os membros dessa platéia puderam produzir suas próprias representações a partir daquelas representações a eles trazidas pelos alunos de Letras.

Não cabe, aqui, iniciar uma comparação entre os dois sistemas de signos utilizados pela fotografia e pelo teatro nem tampouco comparar se a primeira nos traz significados por meio do silêncio de suas imagens e o segundo pela realidade palpável do imaginário da cena que se desenvolve no palco, por meio dos atores e aos olhos dos professores espectadores. As complexidades sígnicas desses dois objetos

3. I am not arguing for a replacement of traditional qualitative research with music, paintings, or film, or that arts-based research is in any way better than traditional qualitative research. What I am arguing is that different educational ideas require different representational forms to be effectively communicated, and that we should begin to experiment with forms other than literature.

4. (Eisner, 1991; 1997; Fordon, 2000; Bochner; Ellis, 2003; Gray, 2003; Slattery, 1997).

5. "Com os dedos sujos de tinta". 
foram e são estudadas no campo da Semiótica, da Fotografia e das Artes Teatrais ${ }^{6}$, e é certo que tais estudos não estão relacionados somente a uma área de conhecimento nem são tarefas para um só pesquisador, mas sim equipes interdisciplinares de pesquisas, tal como mostram as tendências da pesquisa qualitativa nos dias de hoje. A discussão de tais questões, embora muito importante, não é o objetivo deste artigo. Por questões do meu enfoque sobre a educação do professor reflexivo e do tempo e espaço que tive, já iniciei o meu estudo de um determinado ponto do conhecimento nessas áreas.

Acredito que um dos desafios da PEBA, a qual está a dar os seus primeiros passos no mundo (especialmente no Brasil), esteja no âmbito da significação. Isso porque, para significar, é preciso aprender e saber como utilizar os sistemas de signos próprios a cada uma das Artes que o pesquisador em Educação escolhe. A possivel solução que antevejo para tal desafio é o trabalho em conjunto ou em parcerias entre os educadores de professores e os artistas $^{7}$. 1sso, no caso de se almejar um produto artístico final mais elaborado, o qual, acredito, pode ter maiores poderes de comunicação. Entretanto, pelo que tenho percebido na literatura da área, os educadores que trabalham com a PEBA estão pouco preocupados com o produto artístico final dessa modalidade de investigação, mas sim com o processo transformador que ela oferece, o qual objetiva proporcionar a professores e educadores de professores contextos apropriados para que eles expressem os achados de seus estudos e as reflexões por vias alternativas ao tradicional texto verbal e escrito de pesquisa. De certa forma, os dois estudos que apresento em Telles (2005) espelham essa procura: os professores franceses já receberam o objeto de arte pronto, com um alto nível profissional e artístico de elaboração (as fotografias do fotógrafo Robert Doisneau). No estudo brasileiro (Telles, 2004), os alunos de Letras tiveram, primeiramente, que elaborar o objeto de arte (espetáculo teatral) antes de utilizá-lo como dispositivo deflagrador de reflexão. Do ponto de vista de processo educador, o estudo brasileiro parece-me, portanto, mais consoante e completo no que diz respeito aos objetivos da PEBA. Por quê? Porque esse processo educador atinge, como diz Dewey (1934/1974), uma certa culminância e um princípio de contigüidade da experiência educacional de se refletir sobre as questões da escola e do fazer dos professores, representando e culminando os resultados dessa reflexão em forma de uma peça teatral, mesmo que a qualidade desse espetáculo não tenha atingido os desejados níveis artísticos que atores e diretores profissionais de teatro atingiriam ou desejariam.

Assim, no que tange às direções tomadas por essa modalidade de investigação qualitativa, o pesquisador-educador pode partir de, pelo menos, duas vertentes principais ao utilizar a PEBA. Ele pode: a) utilizar o objeto de arte já existente e produzido por um artista (uma fotografia, um filme, uma escultura, um trabalho coreográfico, uma peça de teatro que se encontra em cartaz) ou b) representar suas reflexões e as de seus participantes e seus trabalhos de pesquisa via sistema(s) de signos de uma (ou várias) Arte(s). Em dois estudos apresentados em Telles (2005), utilizei as respectivas vertentes: a primeira, com os professores franceses e, a segunda, com os professores iniciantes brasileiros.

A primeira vertente - a da produção de significados - parece proporcionar ao pesquisador e aos participantes a experiência estética que está centrada na produção de significados por meio de um objeto de arte com o qual eles entram em contato (foi o caso do estudo francês, que utilizou as fotografias de Doisneau). Nessa primeira vertente, o objeto de arte já vem previamente elaborado por um profissional das Artes para deflagrar reflexão. Já na segunda vertente - a da representação -, o educador de professores parece proporcionar ao pesquisador

6. Ver, por exemplo, Féral, 1988; Alba, 1988; Barrientos, 1988; Anspach, 1988; Barthes, 1984; Boal, 1991; 2003.

7. Ver, por exemplo, Saldaña (2003) e sua proposta de dramatizar os dados de uma pesquisa em colaboração com atores. 
e aos participantes da pesquisa oportunidades de expressão por meio de uma determinada Arte; isto é, eles constroem representações dos conhecimentos adquiridos durante a pesquisa e os representam/expressam via objeto de arte. Esse foi o caso do estudo brasileiro descrito em Telles (2004, 2005) - a montagem do espetáculo teatral no e pelo qual os alunos de Letras representaram suas experiências. Nesse segundo caso, especificamente, quanto mais domínio dos sistemas sígnicos daquela determinada Arte o pesquisador (ou educador de professores) e os participantes tiverem, maior serão suas habilidades e seus poderes de representação das experiências educacionais que almejam representar.

Ambas as vertentes, produção de significados e representação, trazem para discussão, acerca da Arte como deflagradora de reflexão, um ponto importante e muito questionado: não se trata de oferecer as Artes como um 'segundo prato', como explora Rolnik (2003), ou querer dar a elas um status por demais pragmático de mera contemplação de beleza. As várias Artes, por elas mesmas, já trazem seu poder educacional; ou seja, a Arte, per se, educa - não somente os sentidos, mas o ser humano em sua totalidade - o espírito e o corpo, ambos em relação dialética, o que Clandinin e Connelly (2000) chamam de embodied knowledge ou conhecimento corporificado ${ }^{8}$. Há também um certo prazer, um sentido de entretenimento e diversão imbuídos nas Artes, os quais permitem àqueles que com elas interagem um sentido de completude e culminância da experiência (Dewey, 1934/1974), assim como um envolvimento de recriação, que não é comumente encontrado em outras formas de atividade humana. Os dois estudos, detalhadamente descritos em Telles (2005), visaram, por meio das interpretações dos professores, provocar o pensamento, o questionamento e a produção de contextos de transformações que tornassem o processo de educação de professores mais humano e inclusivo, pelo qual eles pudessem transformar seus conhecimentos prévios em novos conhecimentos, em níveis intelectuais e emocionais. Já tive oportunidades de desenvolver cursos nos quais não utilizei textos escritos, mas somente filmes e, acredito, tanto quanto os alunos que estiveram no curso, que tais filmes e as discussões que a eles se seguiam muito nos serviram para aprendizagem, compreensão, envolvimento e recriação dos temas educacionais e das experiências por eles suscitadas nesses cursos. Neles, assim como nos dois estudos utilizando a fotografia e o teatro, tentei promover contextos de interação e produção de sentidos entre o objeto de arte, o seu criador (os diretores dos filmes, o fotógrafo Doisneau e os alunos de Letras que compuseram o espetáculo teatral) e as platéias.

Fordon (2005) critica o fato de que, em alguns trabalhos realizados segundo o paradigma da PEBA, os resultados são apresentados de modo a não promover a interação e a compreensão entre o criador e as platéias. Essa autora dá exemplos de museus, concertos, artigos publicados e palestras. Vista dessa perspectiva, a PEBA pode, sim, ser vista como um 'segundo prato', uma oportunidade de consumo na qual não existe insumo de retorno ou aprendizagem mútua entre o produtor e o observador do objeto de arte. Fordon ainda afirma que esse modo de execução dessa modalidade de pesquisa "pode incentivar assimilação unidirecional e a ausência de questionamentos acerca do modo como as metodologias de pesquisa reafirmam ou questionam aquilo que é tradicionalmente válido" (2005, p. 6) pela comunidade acadêmica.

Acredito que, em ambos os processos de pesquisa mencionados neste artigo, estive constantemente preocupado em promover a interação entre o objeto de arte, seu produtor e os professores por meio da reflexão compartilhada. É certo que, no estudo realizado no contexto educacional francês, as oportunidades de interação entre os professores participantes e o produtor das fotografias aconteceu única e

8. Ver, também, Bresler (2004) acerca do abandono do dualismo entre corpo e mente nas pesquisas em Educação e a organização de grupos multidisciplinares de pesquisa formados por especialistas nas Artes e nas Ciências Humanas com o objetivo geral de recuperar o corpo cognitivo no contexto da sala de aula e o papel do corpo no ensino e na aprendizagem. 
exclusivamente por meio das próprias fotografias elaboradas por Doisneau. Desse modo, esse fotógrafo pode falar unicamente por meio de sua arte e não pode responder às recriações de significados dos professores franceses que foram realizadas a partir de suas fotografias. No entanto, acredito que a partir de suas exposições às fotografias de Doisneau, os professores participantes franceses puderam criar suas próprias experiências, realizando atos de abstração e extração daquilo que lhes pareceu significativo nas fotos observadas. Como afirma Dewey:

[...] para perceber, um espectador precisa criar sua própria experiência. E sua criação tem de incluir conexões comparáveis àquelas que o produtor original sentiu. Não são as mesmas, em qualquer sentido literal. Não obstante, com o espectador, assim como com o artista, tem de haver uma ordenação dos elementos do todo que é, quanto à forma, ainda que não quanto aos pormenores, a mesma do processo de organização que o criador da obra experimentou conscientemente. Sem um ato de recriação, o objeto não será percebido como obra de arte. 0 artista [Doisneau, no caso] selecionou, simplificou, clarificou, abreviou e condensou [suas experiências nas fotografias] de acordo com seu ponto de vista próprio e seu próprio interesse. Em ambos tem lugar um ato de abstração, isto é, de extração do que é significativo. (1934/1974, p. 261)

Já no estudo realizado no contexto educacional brasileiro, a interação entre os produtores do espetáculo teatral (os alunos de Letras que o idealizaram e eu - o seu diretor) e os professores não aconteceu somente pelo objeto de arte, mas também pelas conversas reflexivas que pudemos realizar com os docentes. Convém apontar para o fato de que alguns artistas se recusam a explicar suas produções, principalmente aqueles que trabalham com linguagens que não usam a palavra - pintores, coreógrafos, fotógrafos. Para eles, suas artes já dizem o que têm a dizer - falam por si próprias. Explicá-las é cair na linguagem do cotidia- no, do trivial. Já outros artistas se mostram interessados em saber acerca do impacto e das repercussões de seus trabalhos nas vidas daqueles que os apreciam ${ }^{9}$.

Ainda no que diz respeito à participação do observador, as representações oferecidas pelos objetos de arte no estudo realizado (a fotografia e o espetáculo teatral), de certa forma, proporcionaram aos professores participantes um 'mundo virtual', no qual eles puderam se envolver emocionalmente no processo de recriação de detalhes e no escrutínio das representações que trouxeram de suas experiências profissionais. Para Barone (1995), Barone; Eisner (1997) e Eisner (1991), esse envolvimento entre objeto de arte e observador leva à empatia e a um conhecimento mais profundo da pesquisa do que por vias representacionais mais tradicionais.

Por fim, ainda no que tange aos processos de funcionamento dos dois objetos de arte como deflagradores de reflexão, em alguns momentos de meus dois estudos, tais processos não ocorreram sem esforços, conflitos e certos sofrimentos como, por exemplo, no caso de uma professora francesa quando, envolvida por uma das fotografias que lhe foi apresentada, recobra suas histórias pessoais e as de sua própria filha como disléxicas; ou ainda, no caso de uma das professoras brasileiras que expôs a todos os seus colegas sua experiência dolorosa de estresse e tratamento por medicamentos, após presenciar um ato de violência extrema em sua classe. É provável que, por vias mais tradicionais de educação de professores, os processos reflexivos sejam mais seguros, no sentido de não apresentarem tantos desafios e momentos de desequilíbrio e de confronto. Para Greene,

[...] os choques de conscientização produzidos por meio dos encontros com as artes deixam

9. Por exemplo, o Ballet Stagium, companhia paulistana de dança, aproximou, desse modo, na década de 1970, a dança clássica ao público brasileiro ao iniciar a prática de mostrar o aquecimento dos bailarinos, no palco, antes que o espetáculo se iniciasse. Além disso, é comum para essa companhia de dança realizar conversas reflexivas com as platéias, após o espetáculo, a respeito de seu conteúdo, principalmente quando realiza turnês pelo interior do Brasil. 
(ou deveriam deixar) as pessoas menos imersas na rotina do dia-a-dia, mais impelidas a desejar saber e a questionar. (1991, p. 27)

Assim, o encontro dos professores com o objeto de arte tende a colocá-los às margens do dia-a-dia e, para Donoghue,

[...] a margem é o lugar para onde são relegados os sentimentos, as intuições para os quais a vida diária não dá lugar e, na maioria das vezes, parece reprimir. (apud Greene, 1991, p. 27)

Tais esforços, conflitos e sentimentos requerem, da parte do pesquisador que utiliza a PEBA, consideração atenciosa das possíveis conseqüências de sua pesquisa, dos possíveis modos pelos quais os professores interpretarão o projeto de pesquisa e o processo reflexivo e, também, das razões pelas quais eles assim os interpretam. Portanto, à parte da necessidade de o pesquisador e de o educador de professores reconhecerem as transformações pessoais que acompanham os processos de reflexão compartilhada dos professores, existe ainda a responsabilidade de eles voltarem suas atenções para as possíveis dificuldades e para os desafios suscitados pelos objetos de arte como dispositivos deflagradores de reflexão; dificuldades e desafios estes que, certamente, se apresentarão a esses professores ao longo do processo reflexivo.

\section{Experiência estética e a especificidade das reflexões deflagradas pelo objeto de arte}

Seriam as reflexões realizadas pelos professores com os quais trabalhei diferentes se não fossem feitas por meio da fotografia e do espetáculo teatral? Acredito que sim. Diferentemente das reflexões deflagradas a partir de textos escritos em periódicos científicos ou revistas especializadas voltados para a educação de professores, por exemplo, a fotografia e o espetáculo teatral proporcionaram um acesso ao inefável de suas experiências educacio- nais e profissionais, um acesso à experiência estética nos termos de Dewey (1934/1974). Os três excertos de professores franceses e brasileiros, abaixo, ilustram essa relação estética entre os participantes e os dois objetos de arte utilizados:

Quando se vai ao redor da mesa [sobre a qual estavam as fotos], na verdade, somos já tocados pela emoção, porque essas fotos são plasticamente belas, esteticamente muito belas, trata-se de Doisneau [...] que fala, que sempre soube apreender o instantâneo, o pequeno detalhe revelador de comportamentos [...], onde se tem, ao mesmo tempo em que se olha para essas imagens, essas fotografias, uma reativação de imagens pessoais, do vivido. [CA4GRIV: 68-75] ${ }^{10}$ $\mathrm{F}^{11}$ : Tenho a impressão que esta foto é muito poética porque a criança está, talvez, em situação de punição e, ao mesmo tempo, há qualquer coisa de sonho, de poesia... [CA4GRIV: 192-4] ${ }^{12}$ [...] a gente tem um quadro aí que a gente já conhece, as pessoas se identificam imediatamente quando vêem certas cenas [do espetáculo teatral] e se emocionam porque é verdade, porque é real, está muito próximo à pele de todo mundo, de todo professor. [DP: 152-5]

Santagada toma a experiência estética promovida por espetáculos teatrais (acredito que, também, promovida pelas fotografias, pelo modo como elas foram utilizadas em meu estudo - por meio de oficinas de fotografias),

[...] como um tipo de desafio lançado aos espectadores, o qual está inerentemente vinculado ao contexto cultural no qual circulam os bens simbólicos restantes e a natureza coletiva da vivência

10. Quand on fait ce tour de table, en fait, on est déjà saisi par l'émotion, parce qu'en fait ces photos sont plastiquement très belles, esthétiquement très belles, c'est Doisneau [...] qui parle, qui a toujours su saisir l'instantané, le petit détail révélateur des comportements [...]. Où on a, à la fois, en regardant ces images, ces photos, une réactivation d'images personnelles, de vécu. [CA4GRIV: 68-75]

11. Por questões de confidencialidade, nas transcrições dos dados, os participantes são identificados pela letra inicial de seus nomes.

12. F: Moi je trouve que cette photo elle est très poétique parce que l'enfant il est peut-être en situation de sanction, et en même temps il y a quelque chose de rêverie, de poésie... [CA4GRIV: 192-4] 
na sala de espetáculos [ou nas salas onde ocorreram as oficinas de fotografias]. (2004, p. 6)

Considerada de tal ponto de vista da experiência estética, acredito que a PEBA colocou diferentes tipos de 'desafios' frente aos professores que participaram do estudo francês (reflexão pela imagem das fotografias) e frente aos professores, alunos e pais que assistiram ao espetáculo teatral, no caso do estudo brasileiro (reflexão pelo espetáculo teatral). Esse último pareceu-me mais completo, em virtude de proporcionar uma maior inclusão de todos aqueles que participam do processo educacional - professores, alunos, educadores de professores e pais. Esses desafios apresentaram condições que dependeram (não exclusivamente) de suas sensibilidades e de suas histórias de vida, as quais, provavelmente, puderam ser afetadas de acordo com os múltiplos modos pelos quais os participantes experienciaram as fotografias, o espetáculo teatral e as conversas reflexivas. Acredito que a PEBA e as reflexões compartilhadas também forneceram aos participantes o contexto interativo, social e profissional apropriado para que eles pudessem se entender, durante as reflexões compartilhadas, a respeito de 'eventos objetivos' (olhar as fotos, assistir ao espetáculo teatral), os quais lhes causaram, "impressões particulares em seus mundos íntimos” (Santagada, 2004, p. 6). Em tal processo de entendimento, os participantes tentaram superar os desafios lançados pela fotografia e pelo espetáculo teatral, funcionando como dispositivos deflagradores de reflexão. Minhas referências teóricas sobre a teoria da recepção teatral são, portanto, sociointeracionais - da interação do indivíduo com o mundo que o cerca (e logicamente considerando o fato de que tal interação é mediada pelas linguagens). Tal referência teórica se fundamenta no caráter social da representação estética, a qual, de acordo com Lucero (2005), "surge no momento da identificação com a obra de arte interagindo com as impressões e conhecimentos do sujeito" (p. 1).
Santagada me dá subsídios para posicionar a própria reflexão compartilhada como um meio pelo qual a experiência estética é concretizada, já que tal reflexão se deu essencialmente por meio da palavra (as interações verbais por meio das conversas reflexivas), pelo menos nos dois estudos aqui tratados. Para ele, a experiência estética:

[...] se concretiza por meios verbais. A superação dos desafios lançados por um espetáculo [ou pelas oficinas de fotografias] não é uma experiência inefável, mas que pode ser descrita por meio dos jogos lingüísticos [as conversas reflexivas], nos quais os participantes intervêm com o intuito de atingirem compreensões de um evento objetivo [assistir ao espetáculo, olhar as fotos] que thes tenham causado impressões particulares no mundo íntimo de cada um deles. Achamos que esses jogos lingüísticos [durante a reflexão compartilhada e as oficinas de fotografias, no caso] sejam a concretização de uma experiência estética que um espectador [ou admirador de uma fotografia] efetua com base de sua vivência do espetáculo [ou observação de uma determinada foto]. (2004, p. 06)

Nos casos específicos das reflexões deflagradas pela fotografia e pelo espetáculo teatral (aqui considerados como dispositivos deflagradores de reflexão), ambos provocaram processos de produção de significados de modo individual em uma primeira instância; isto é, cada professor, membro da platéia, que assistiu ao espetáculo teve um (certo) espaço para refletir sobre o que viu (reflexão sobre a ação, aos moldes de Schön, 1983; 1991; 1987) e produzir seus próprios sentidos àquilo que lhe foi apresentado. Se tais significados foram ou não submetidos a um escrutínio crítico pelo participante da pesquisa, não é possivel saber, pelo menos até o momento em que ele os exteriorize a outrem, por meio da reflexão compartilhada. Acredito que esse modo individual de reflexão, o qual me pareceu tão criticado por Pimenta e Ghedin (2002) quando trata do 
trabalho de Schön (1983), é o primeiro passo reflexivo que se inicia no âmbito da pessoa.

No entanto, se essas produções individuais de significados permanecerem meramente no âmbito da pessoa, corre-se o risco de eles serem legitimados, propagados e até perpetuados sem o exame atento (ou um escrutínio) de seus pressupostos e das ideologias que a eles vêm associadas. $\mathrm{Na}$ verdade, ninguém constrói significados do vácuo - eles são reflexos das experiências do indivíduo e das ideologias existentes no campo social no qual se dá o processo reflexivo. lsso porque os indivíduos ‘habitam e são habitados' por tal campo, como sugere (Rolnik, 1993). Assim sendo, uma professora evangélica e outra feminista que assistam ao mesmo espetáculo teatral, ou vejam as mesmas fotografias, construirão significados com base em diferentes ideologias, dadas as histórias por elas vividas em seus respectivos contextos sociais, as quais fazem com que ambas construam diferentes representações, muitas delas vistas como naturais e não naturalizadas (Fairclough, 1992).

É por acreditar que as pessoas aprendem por meio das relações sociais nas quais estão engajadas que acredito que a prática social da PEBA, para e entre professores, alunos e pais de alunos, possa dar uma importante contribuição às formações profissionais dos primeiros e à reconstrução de representações da prática pedagógica e do ensino para todos aqueles envolvidos no processo educacional. As qualidades formativas da PEBA, evidenciadas nos dois estudos pelas duas atividades realizadas - fotografia e espetáculo teatral - e das conversas reflexivas, visaram à articulação de contextos interativos ${ }^{13}$. Nesses contextos, os participantes dos dois estudos puderam expressar, em primeiro lugar, seus significados individuais aos outros e, a partir desses significados, construir outros, dessa vez de forma compartilhada. Em segundo lugar, ainda nesses contextos interativos nos quais a linguagem teve um enfoque central, os professores puderam compartilhar suas representações com os colegas de profissão a partir das fotografias e do espetáculo teatral, submetendo-os às opiniões e aos qua- dros de referência de outros colegas profissionais. Contudo, tanto os processos como os resultados transformadores desse compartilhamento de significados não são tão simples, naturais e automáticos como possam parecer. Vista como um momento de socialização dos significados individuais de professores, alunos e pais participantes, a reflexão compartilhada funciona como um evento que toma múltiplas direções, dependendo de seus participantes e do educador de professores que medeia o processo reflexivo. Uma dessas múltiplas direções diz respeito à transformação das representações e parece estar contida no que eu chamaria de um continuum bipolar de intensidade transformadora. De um lado desse continuum, mesmo já não estando no âmbito individual e já no âmbito coletivo, os participantes e o(s) mediador(es) desse tipo de reflexão podem propagar, legitimar, solidificar e perpetuar representações equivocadas e falaciosas das experiências suscitadas pelos objetos de arte e pela própria reflexão compartilhada. Do outro lado desse mesmo continuum, a socialização de significados individuais, uma vez expressos entre indivíduos que trazem à prática social da reflexão compartilhada uma diversidade de quadros de referências do mundo no qual vivem, pode questionar a validade, desconstruir e, ainda, ressignificar esses significados que foram construídos no âmbito restrito de uma só pessoa. Essa tal intensidade transformadora é freqüentemente sentida após sairmos de uma atividade reflexiva entre professores com sensações ou de insatisfação ou de libertação catártica em relação às metas para se atingir um certo sentido de culminância (Dewey, 1943/1974) das interações ocorridas durante a atividade reflexiva.

Sendo os indivíduos participantes da reflexão compartilhada diferentes uns dos outros, é evidente o fato de que a intensidade transformadora varie de sessão para sessão e de indivíduo para indivíduo que dela participe.

13. Como professor e de acordo com Viola Spolin ( 1976), acredito que 'não ensino nada a ninguém', mas sim articulo contextos que favoreçam ou promovam a aprendizagem por meio das interações travadas entre os indivíduos (meus alunos). 
Variante e sensível a essas múltiplas diferenças individuais e sociais e também ao grau de abertura aos afetos de cada um dos indivíduos participantes, a reflexão compartilhada carrega, portanto, em seu bojo, as múltiplas e dominantes ideologias dos contextos sociais nos quais ela ocorre. Assim sendo, ela nunca é e nunca será neutra e sempre será ideologicamente direcionada. A questão é estar ou não consciente e estar ou não aberto às múltiplas direções ideológicas tomadas durante tal processo reflexivo. Mesmo sendo a base do teatro, tal intensidade transformadora será, portanto, dependente da comunidade na qual ele é praticado ${ }^{14}$.

Ainda sob o enfoque da perspectiva processual desse tipo de reflexão, os estudos com as fotografias e com o espetáculo teatral serviram para evidenciar a importância do papel do mediador durante a realização da conversa reflexiva. Uma autocrítica que faço a esses meus dois estudos é que, devido às condições as quais eu dispunha, realizei-o sozinho, sem estar associado a um grupo de educadores de professores que comigo trabalhassem e compartilhassem tais experiências de formação e de mediação das reflexões compartilhadas. Tal ação formadora e intervencionista pode se tornar perigosa, porque se corre o risco de o mediador se tornar um 'pregador', 'doutrinador' ou 'manipulador' que conduz as reflexões segundo as ideologias que ele próprio abrace, caso os participantes não sejam suficientemente críticos para percebê-las e caso, ainda, esse mediador não seja suficientemente aberto às diversidades de posições e de idéias que emergem nas sessões de reflexão compartilhada. Assim, seria mais apropriado que essas sessões fossem mediadas por 'grupos' formados de educadores de professores, professores, alunos e pais de alunos, os quais devem expressar e deixar transparentes aos participantes as ideologias e os paradigmas de educação e reflexão que abraçam.

Mediadores de reflexão compartilhada também devem ser educadores de professores que possuam, além de suas experiências práticas, o conhecimento de certos paradigmas e referenciais teóricos que possam contribuir e colaborar com os professores em seus processos de ressignificação e estruturação das experiências profissionais e pedagógicas durante a reflexão compartilhada. Pelo fato de trabalhar individualmente nos dois projetos de pesquisa aqui mencionados, sempre estive atento aos educadores de professores presentes nas platéias que assistiram aos espetáculos. Como mediador das conversas reflexivas, sempre tentei suscitar as opiniões desses educadores presentes às reflexões, evitando dar respostas e redirecionando as perguntas que a mim eram feitas aos participantes dos grupos e das platéias. lsso para que esses participantes não estivessem sujeitos àquilo que eu lhes apresentava como objetos deflagradores de reflexão e aos meus próprios modos de pensar a educação e de conduzir o processo reflexivo compartilhado.

0 conhecimento teórico dos educadores de professores e dos professores participantes se faz, assim, necessário. No entanto, a capacidade dos docentes de teorizarem suas próprias experiências do fazer pedagógico não deve ser menosprezada. As teorias construídas pelos professores a partir de suas práticas devem estar em relação dialética com, como diz Clandinin e Connelly (1995), as teorias codificadas nos livros. Mediadores de reflexões compartilhadas, quando bem informados e teoricamente atualizados, podem acelerar tanto o ritmo e a direção da reflexão assim como o processo de organização teórica dessas experiências e das práticas dos docentes. Tais qualidades de mediadores fazem com que os professores participantes da conversa reflexiva se tornem sujeitos de suas próprias histórias e agentes que se apropriam não somente do processo de construção dos conhecimentos acerca do ofício de ensinar, mas também da palavra. Durante as conversas reflexivas, os professores podem, em público, tornar seus discursos pedagógicos instrumentos de empoderamento, de transformação e de expressão e não um mero conjunto de ruídos e de manipulação ideológica. Ademais, os educadores,

14. Por exemplo, a intensidade transformadora do filme 0 segredo de Brokeback Mountaine o talento de seu diretor, Ang Lee, podem ser questionados na China, onde nem o filme nem o seu sucesso foram divulgados, pelo fato de tratar de temas ditos incompatíveis com aquela sociedade e seus membros. 
atuando como mediadores de reflexões compartilhadas podem, por meio da inserção de seus conhecimentos e suas experiências prévias, assegurar uma boa margem do potencial transformador a elas inerente. Eles podem facilitar esse processo de empoderamento, fazendo com que os professores participantes da reflexão compartilhada não partam da 'estaca zero' ou da 'descoberta da roda' e, assim, possam avançar em direção a temas e níveis reflexivos mais profundos, que não se restrinjam às práticas do dia-a-dia da sala de aula.

A exposição dos professores aos dois objetos de arte deflagradores de reflexão (fotografia e espetáculo teatral) também permitiu que a reflexão compartilhada contivesse os elementos apontados por Valadares (2002) para uma prática reflexiva transformadora: a) a intencionalidade do fazer educativo, b) a experimentação e c) o enfrentamento de situações complexas. Desafiados a produzirem significados e a compreenderem esses objetos de arte por meio da mediação da reflexão compartilhada, os professores problematizaram suas práticas sociais do ensino, das escolas e da profissão, revelando não somente a intencionalidade do fazer educativo como também o desejo de enfrentar situações complexas existentes nas escolas (lembro, como exemplo, questões colocadas pelos professores participantes a respeito dos conflitos sociais trazidos pelos alunos para a escola, as tensões decorrentes da indisciplina etc.). De certa forma, os dois estudos que conduzi se constituíram em minhas estratégias de enfrentamento, como educador de professores, das situações complexas da prática de ensino dos professores e de meu trabalho como educador de professores na universidade.

Por fim, ainda no que diz respeito às especificidades das reflexões compartilhadas e à experiência estética, posso dizer que, como educador de professores, coloco-me em direção à educação estética desses docentes. Acredito que, por meio da PEBA e de análises cuidadosas de certos objetos de arte, é possível obter resultados relevantes no que tange às sensibilidades dos educadores em relação ao ensino.
A própria aula e o ato de ensinar, se vistos de uma perspectiva estética, poderão ser considerados como Artes. Vejamos o que diz a filósofa da arte - Maxine Greene, no site do Lincoln Center Institute, de Nova York, quando descreve as oficinas destinadas à educação estética de docentes que lecionam Artes nas escolas:

Observações e analises cuidadosas de certos trabalhos artísticos estão ligados às atividades planejadas pelos artistas-professores com o intuito de realçar a possivel relação entre as escolhas do artista e a resposta estética do observador. Por meio de suas explorações enquanto fazem arte, os participantes integram suas experiências e percepções para construir novas compreensões de um determinado objeto artístico e, freqüentemente, de seus mundos. Não se trata de uma abordagem que vise a ensinar a 'arte pela arte' nem de uma abordagem que vise ao uso das artes para ensinar outras matérias. Trata-se, sim, de um terceiro processo que incorpora alguns elementos de ambas as abordagens - uma abordagem que envolve percepção, cognição, afeto e imaginação. ${ }^{15}$

Greene (1995) sustenta o pressuposto de que a compreensão de um trabalho artístico se dá na relação entre o individuo que aprecia e o objeto de arte e não no próprio objeto. Assim, de tal pressuposto, é possível construir várias práticas de educação estética de professores e alunos, como as do Lincoln Center Institute. Fundamentado nesse pressuposto de Greene e de sua filosofia da arte, esse instituto oferece, em suas oficinas pedagógicas, alguns passos que podem ser tomados pelos professores que estão interessados em construir

15. Carefully planned observations and analyses of particular works of art are connected to participatory activities designed by teaching artists to highlight the possible relationship between an artist's choices and the viewer's aesthetic response. Through art-making explorations in performing and visual arts, participants integrate their experiences and perceptions to shape new understandings of a particular artwork, and often, their world. This approach is neither teaching "art for art's sake," nor using the arts as a vehicle for teaching other subjects. Rather it is a third process that incorporates some of the elements of both, involving perception, cognition, affect, and the imagination. [Lincoln Center Web Site. http:// www.lincolncenter.org/. Acessado em 26 setembro de 2005] 
contextos reflexivos que propiciem oportunidades aos alunos para o desenvolvimento de experiências estéticas. Esses passos são:

a) Descrição - requer do aluno a descrição dos elementos visuais da obra de arte (o que ele vê e o que ele escuta), tais como: cenário, apetrechos, figurinos de uma peça, os movimentos no palco e o posicionamento dos artistas no espaço, as cores, linhas e imagens de uma pintura, por exemplo.

b) Análise - requer a atenção do aluno para as escolhas realizadas pelo artista para compor o seu objeto de arte, um exame dos elementos que compõem a obra e como eles se relacionam um com o outro; o modo como os elementos tempo, dinâmica e acentos sugerem uma determinada sensação ou até mesmo uma história; a maneira como as escolhas de cenários, apetrechos, figurinos dão apoio à idéia da obra de arte; as formas e os gestos que são utilizados e como eles indicam a idéia, a personagem e a história; as relações que têm os personagens e os objetos em cena, na coreografia ou na pintura; e como é apresentada a obra enquanto ela se desenvolve.

c) Especulação e/ou interpretação - requer do aluno uma reflexão acerca dos possíveis significados da obra de arte, utilizando as informações coletadas nas fases de descrição e análise acima expostas. Com isso, questiona quais idéias e sensações o artista desejou expressar, as questões com as quais o artista ou diretor do filme ou peça de teatro estavam preocupados, quais os fatos da vida do aluno vieram à sua cabeça enquanto observava o objeto de arte, os significados pessoais que o objeto de arte teve para ele, possibilidades de outros significados e o significado desse objeto de arte para uma sociedade futura.

d) Avaliação - é entendida como o valor que damos a um objeto de arte enquanto o percebemos ou uma afirmação fundamentada por uma evidência contida no próprio objeto de arte. Nessa perspectiva, entende-se que suspender qualquer tipo de avaliação e julga- mento durante o processo de descrição, análise e interpretação é algo artificial. 0 importante é articular razões para as nossas avaliações. Entendida dessa maneira, avaliação é uma afirmação apoiada em evidências contidas no próprio objeto de arte.

Os passos, acima, levaram-me a crer que, provavelmente, durante boa parte do tempo das oficinas de fotografias, das apresentações dos espetáculos teatrais e das respectivas reflexões compartilhadas que se seguiram, estive trabalhando e elaborando as experiências estéticas dos meus participantes, enquanto eles refletiam acerca dos objetos de arte a eles expostos como dispositivos deflagradores de reflexão. Assim, foi por meio desses trabalhos de pesquisa, de minhas leituras acerca dos assuntos pertinentes e de minhas reflexões sobre o processo que atingi uma certa compreensão daquilo que eu estava fazendo com os professores por meio da PEBA e das experiências que tal modalidade de pesquisa pode oferecer para uma Educação Estética dos professores, dos alunos e dos pais que comigo estiveram envolvidos. Evidências dessas afirmações podem ser constatadas no Quadro 1, no qual fiz um elenco de excertos das reflexões compartilhadas (coluna à direita) que corroboram com os passos do processo de pesquisa estética, tal qual proposta por Greene (1995).

Assim, a especificidade das reflexões deflagradas a partir dos dois objetos de arte utilizados em cada um dos dois estudos esteve ligada ao potencial que eles tiveram de oferecer aos participantes dos contextos reflexivos, caracterizados pela liberdade para se produzir significados a partir dos desafios lançados a eles pelos objetos. Antes de eu oferecer as fotografias aos professores franceses e de eu e os alunos de Letras oferecermos as apresentações do espetáculo teatral, havíamos nós mesmos passado por um processo reflexivo o qual, de certa forma, compreendia a seleção e escolha dos conteúdos que foram oferecidos por ambos os objetos utilizados. No entanto, a 
Quadro I: Alguns passos da experiência estética que foram tomados pelos professores durante as reflexões compartilhadas.

\begin{tabular}{|c|c|}
\hline PROPOSTA DE GREENE (1995) & EXCERTOS DAS REFLEXÕES DOS PARTICIPANTES \\
\hline \multicolumn{2}{|l|}{ DESCRIÇÃO } \\
\hline Descreva 0 que você vê e escuta. & $\begin{array}{l}\text { H2: Sim, } 60 \text { anos atrás, totalmente, minha escola quando eu tinha dez anos. } \\
\text { Os banheiros, o relógio, os bancos, tudo enfim, tem a ardósia... } \\
\text { [CA3GRVl:13-4] }\end{array}$ \\
\hline $\begin{array}{l}\text { Quais elementos visuais compõem a cena, tais como } \\
\text { o cenário, apetrechos, figurinos etc.? }\end{array}$ & $\begin{array}{l}\text { F: Depois existe um outro vivido, é porque é um novo, não tem os mesmos } \\
\text { guarda-pós, ele não está vestido do mesmo jeito e ele segura sua mochila } \\
\text { desse jeito e ele tem, pensei nos óculos, mas também ele tem um guarda-pó } \\
\text { que é diferente, que é de tecido xadrez que é claro e todo mundo está de } \\
\text { escuro, todo mundo deve ter guarda-pós que devem ser um pouco mais } \\
\text { curtos. [CA3GRVl: 459-64] }\end{array}$ \\
\hline $\begin{array}{l}\text { Descreva as entradas e saídas, os movimentos no } \\
\text { palco e como os artistas se posicionam no espaço. }\end{array}$ & $\begin{array}{l}\text { A cena se passa logo quando termina o quadro dos professores, vem a Maria } \\
\text { Eduarda, que é a professora. Ela chama pela diretora, é uma diretora, a Leila } \\
\text { e a diretora... Ela diz de um aluno, que depois vai aparecer - } 0 \text { Jubileu -, que } \\
\text { está querendo se integrar ao grupo, mesmo com toda a dificuldade. A } \\
\text { professora tem uma troca com a diretora, porque é emprestado um material, } \\
\text { ela vem conversar. Existe uma parada, bem no centro. Nada é à toa. Parou } \\
\text { bem do centro [do palco] para mostrar proximidade. [DP: } 258-66 \text { ] }\end{array}$ \\
\hline $\begin{array}{l}\text { Descreva as cores, as linhas, as imagens de uma } \\
\text { pintura. }\end{array}$ & [não houve exemplos] \\
\hline \multicolumn{2}{|r|}{ ANÁLISE } \\
\hline $\begin{array}{l}\text { Que escolhas } 0 \text { artista teve que fazer para criar a sua } \\
\text { obra? }\end{array}$ & [não houve exemplos] \\
\hline $\begin{array}{l}\text { Faça um exame dos elementos que compõem a obra } \\
\text { e como eles se relacionam um com o outro. }\end{array}$ & $\begin{array}{l}\text { [...] vemos que, evidentemente as crianças usam guarda-pós etc., mas há } \\
\text { um certo número de clichês que poderiam estar coloridos atualmente, com } \\
\text { outros tipos de roupas etc., mas que revelam comportamentos que são, na } \\
\text { verdade, permanentes, idênticos, isto é, aqui nós nos reencontramos } \\
\text { enquanto alunos e, ao mesmo tempo, observamos detalhes de } \\
\text { comportamentos de nossos próprios alunos, porque nisso tem o tédio, tem a } \\
\text { marginalização, tem tudo aquilo que pudemos viver e que nossos alunos } \\
\text { ainda vivem [...]. [CA4GRIV: } 76-84]\end{array}$ \\
\hline $\begin{array}{l}\text { De que modo os elementos tempo, dinâmica e } \\
\text { acentos sugerem uma determinada sensação ou até } \\
\text { mesmo uma história? }\end{array}$ & $\begin{array}{l}\text { Porque ela [a personagem 'pedagoga'] não faz nenhuma intervenção, gente! } \\
\text { Ela assiste, ela acha todos lindos, mas ela não tem coragem de fazer UMA } \\
\text { intervenção! Ela só colhe os dados. Fiquei emocionada, gente! [DP: 100-3] }\end{array}$ \\
\hline $\begin{array}{l}\text { De que maneira as escolhas de cenários, apetrechos, } \\
\text { figurinos dão apoio à idéia da obra? }\end{array}$ & $\begin{array}{l}\text { Sim, é a liberdade do aluno, a liberdade de olhar a hora na foto } 13 \text { mesmo } \\
\text { que o professor tenha pedido para olhar para frente, isso evoca para mim, ao } \\
\text { mesmo tempo, a ordem, a obediência e a capacidade individual de poder } \\
\text { imaginar, de sonhar por que não, em uma foto de criança que olha pela } \\
\text { janela ou que chupa seu lenço [...]. Eis o que isso evoca. [CA1-2GRIII: } 34-9 \text { ] }\end{array}$ \\
\hline $\begin{array}{l}\text { Que formas e gestos são utilizados e como eles } \\
\text { indicam a idéia, personagem e história? }\end{array}$ & $\begin{array}{l}\text { [...] uma coisa que me emociona muito nessa peça é na hora da professora } \\
\text { de Inglês, que ela está dando aula, ela bate no Jubileu - pah! Menino, } \\
\text { responde! Parece que é uma coisa tão assim, né, são opostos da questão, } \\
\text { né. Aquela mulher toda preocupada com coisas e formas da língua e aquele } \\
\text { menino que não está nem aí, né? [DP: 107-12] }\end{array}$ \\
\hline Que relações têm os personagens? E os objetos? & $\begin{array}{l}\text { Você viu que isso daí, alguma coisa retratada em algum dos personagens? } \\
\text { Você lembra qual que é ou não? [DR: } 36-7] \\
0 \text { professor também não se envolveu com o aluno e o aluno não se envolveu } \\
\text { com o professor. Então, ficou uma coisa extremamente fria que, na realidade, } \\
\text { nós que trabalhamos em uma escola pública, hoje, não é isso. [DR: 11159-62] }\end{array}$ \\
\hline $\begin{array}{l}\text { Enquanto é apresentada, de que forma a obra se } \\
\text { desenvolve? }\end{array}$ & $\begin{array}{l}\text { Ele realmente passa batido, né, o professor. Ele não se envolve. Ele não se } \\
\text { envolve! } 0 \text { problema do professor na caracterização delas é que ele não se } \\
\text { envolve. E às vezes a gente vê isso na realidade, mas em grande parte } 0 \\
\text { professor não consegue resolver. [DR: } 140-4 \text { ] }\end{array}$ \\
\hline
\end{tabular}




\begin{tabular}{|c|c|}
\hline \multicolumn{2}{|c|}{ ESPECULAÇÃO/INTERPRETAÇÃO } \\
\hline $\begin{array}{l}\text { Utilizando as informações coletadas na descrição e } \\
\text { análise, pense nos possiveis significados dessa obra } \\
\text { de arte. Essas interpretações devem nos levar por } \\
\text { direções mais profundas à obra de arte e não nos } \\
\text { afastar dela. }\end{array}$ & $\begin{array}{l}\text { É que eu observei... essa é a realidade da sala de aula, né? Os alunos } \\
\text { completamente diferentes um do outro e o professor ali... completamente fora } \\
\text { da realidade, né, huh... em cima do sapato, do salto... Nem mal olha } 0 \text { aluno, } \\
\text { não quer saber } 0 \text { que se passa com } 0 \text { aluno, não quer ter um contato mais } \\
\text { direto com } 0 \text { aluno, né. Eu percebi a pessoa, achei superinteressante isso } \\
\text { [RP:74-79] }\end{array}$ \\
\hline 0 artista queria expressar quais idéias? & $\begin{array}{l}0 \text { objetivo da peça, também, é estar despertando a curiosidade, porque tem } \\
\text { muita gente que não conhece ainda, né? [DP: } 53-4]\end{array}$ \\
\hline $\begin{array}{l}\text { Quais são algumas das questões com as quais } 0 \\
\text { artista/diretor estava preocupado? }\end{array}$ & $\begin{array}{l}\text { [...] eu gostaria que essa peça servisse tanto para aluno quanto para } \\
\text { professor refletirem um pouco sobre o quão omissos eles estão sendo. [DA: } \\
679-81] \\
\text { A peça toca, em vários momentos, a respeito da competência e da pessoa do } \\
\text { professor na língua estrangeira. (DP: } 61-2]\end{array}$ \\
\hline $\begin{array}{l}\text { Enquanto você observava o objeto de arte, que fatos } \\
\text { da sua vida vieram à sua cabeça? }\end{array}$ & $\begin{array}{l}\text { [...] essa peça me fez voltar tudo, né, de novo, vi também alguns erros meus, } \\
\text { né. Me fez refletir. Por exemplo, a cobrança de livros, eu cobro isso do aluno, } \\
\text { né... A cobrança: por que não trouxe, por que não comprou? Então, eu me vi } \\
\text { nessa situação, tá. Obrigada. [DC: 109-12] } \\
\text { H: É a lembrança, as coisas que me surpreendem porque não a vemos mais } \\
\text { enfim, não vemos relógio desse tipo ou de banheiros desse tipo, acho. } \\
\text { [CA3GRVl: } 22-4]\end{array}$ \\
\hline $\begin{array}{l}\text { Que significado pessoal tem essa obra de arte para } \\
\text { você? }\end{array}$ & $\begin{array}{l}\text { Bom, meu nome é Sandra, eu sou... eu não sou de Letras e... eu vou } \\
\text { concordar muitíssimo com você porque [a peça] toca questões de estereótipo, } \\
\text { porque eu sou pedagoga!!! [...] Quando eu vi... aquilo me assustou } \\
\text { tremendamente!!! [DP: 79-81] }\end{array}$ \\
\hline Que outros significados ela poderia ter? & $\begin{array}{l}\text { [...] essa daqui era a foto } 24 \text {, é positiva para mim, representa o esforço, } 0 \\
\text { esforço do trabalho e a vontade de trabalhar, e disso eu tinha vontade, essa } \\
\text { foto aqui, eu não a vejo nem um pouco como uma criança que está olhando } \\
\text { para a hora. [CA1-2GRIll: 109-13] }\end{array}$ \\
\hline $\begin{array}{l}0 \text { que esta obra de arte significaria para uma } \\
\text { sociedade futura? }\end{array}$ & $\begin{array}{l}\text { Um aluno do segundo ano falou: "Mas o que é PCNs??? Né? Eu achei muito } \\
\text { marcante isso porque os alunos que estão entrando... é importante eles } \\
\text { estudarem desde o início, porque, aliás eles vão ser os futuros professores. } \\
\text { Eu acho importante ressaltar essa questão de estar consciente, de querer } \\
\text { transformar o ensino. [DR: 74-9] }\end{array}$ \\
\hline & AVALIAÇÃO0 \\
\hline $\begin{array}{l}\text { Avaliação é uma afirmação fundamentada por uma } \\
\text { evidência contida no próprio objeto de arte. }\end{array}$ & $\begin{array}{l}\text { Tenho impressão que por meio dessas fotos que representam um tipo de } \\
\text { escola, existe algo de eterno que se parece com o que eu vivi, algo que..., por } \\
\text { exemplo, a ordem: a foto } 2 \text {, com os alunos em ordem, } 0 \text { vivido muito forte } \\
\text { das crianças que bagunçam ou que brincam no pátio, como na foto } 8 \text {, das } \\
\text { crianças que se aborrecem na foto } 10 \text {. [CA1-2GRIII: } 20-5 \text { ] }\end{array}$ \\
\hline $\begin{array}{l}\text { Avaliação é o valor que damos a um objeto de arte } \\
\text { enquanto o percebemos. }\end{array}$ & $\begin{array}{l}\text { F: Tenho a impressão que esta foto é muito poética porque a criança está, } \\
\text { talvez, em situação de punição e, ao mesmo tempo, há qualquer coisa de } \\
\text { sonho, de poesia... [CA4GRIV: 192-4] }\end{array}$ \\
\hline
\end{tabular}

adequada liberdade para refletir acerca dos conteúdos que os participantes das oficinas de fotografias e os membros das platéias acharam relevantes serviu para que esses participantes percorressem os passos de descrição, análise, interpretação e avaliação dos conteúdos sugeridos pelos objetos de arte.

É por essas razões que vejo a PEBA como um instrumento propício ao desenvolvimento de um trabalho emancipador no campo da educação de professores. É também pela liberdade de escolha, por ela dada aos partici- pantes, para que estes optem por seus próprios caminhos por meio do compartilhamento de problemas e de idéias do ofício de ensinar. Tais oportunidades reflexivas são empoderadoras e permitem que os professores tomem a palavra para, em público, compartilharem suas representações eliciadas pelos objetos de arte. Não se trata, de acordo com Greene (1995), de fazer um uso utilitarista das Artes para realizar algum determinado trabalho pedagógico - a Arte como 'segundo prato', como diz Rolnik (2003). Trata-se, sim, de pôr em marcha um pro- 
jeto de Educação Estética dos professores, dos alunos e dos pais o qual, per se, trará os benefícios e o nutrimento de um projeto educativo e transformador de professores em direção à reflexão, à imaginação, à expressividade, à apreciação das diferenças, à busca de significados no/do mundo e a um aprender a aprender (Greene, 2001).

\section{Considerações finais}

\section{A PEBA, seu funcionamento e sua relação com o desenvolvimento do professor}

Ao propor, aqui, uma educação transformadora de professores por meio da PEBA e da reflexão crítica como forma de apreciar a validade das pressuposições pertencentes ao corpo de significados de um indivíduo e um exame de suas fontes e conseqüências (Mezirow, 1991), devo perguntar-me: quais ações emancipadoras realmente executam os professores em seus contextos profissionais após saírem de uma reflexão compartilhada e deflagrada pelo espetáculo teatral ou pela fotografia? Pelos dois estudos que realizei, não foi possível constatar ações emancipadoras tomadas pelos professores após saírem de uma reflexão compartilhada. Para isso, seria necessário que eu os acompanhasse durante um determinado período de tempo. Não obstante, foi possivel observar algumas dessas ações dos professores participantes $d u$ rante as reflexões compartilhadas, tais como a revisitação e organização de suas experiências, a articulação de um discurso a ser compartilhado com os outros colegas da reflexão compartilhada, a tomada da palavra, em público, para a exposição dos danos de suas formações e do exercício profissional. 0 funcionamento da PEBA adquiriu, desse modo, um caráter emancipador com relação ao desenvolvimento profissional do professor. Essa modalidade de pesquisa assegurou aos participantes meios representacionais para a exposição das representações acerca dos componentes e dos eventos do ofício de ensinar. Associada à reflexão compartilhada e deflagrada pelo objeto de arte, a PEBA convida seus participantes a articularem seus conhecimentos situados dentro de contextos reflexivos nos quais indivíduos diferentes compartilham histórias de vida e experiências pedagógicas diferentes, desafiadas pelos objetos de arte. Esses últimos convidam os participantes da pesquisa a pensarem acerca de questões pertinentes às suas experiências vividas nos contextos institucionais e nas relações sociais em que estão inseridos.

Assim, ao questionar-me acerca de quais ações emancipadoras poderiam tomar os professores após saírem de uma reflexão deflagrada pelos dois objetos de arte utilizados neste estudo, penso nas condições de reflexividade que foram oferecidas aos meus participantes por meio das linguagens fotográfica e teatral. Por elas, foi possivel pensar e expressar, de forma alternativa, o mundo pessoal e profissional do professor - um modo alternativo à linguagem verbal, tão comumente usada. Tal fato abre perspectivas e modos diferentes de se pensar a educação de professores que são diversos daqueles que freqüentemente vemos nas universidades e nos programas de educação continuada.

De certa forma, devo pensar, também, em três limitações desses meus dois estudos, as quais se mostraram claras ao longo do processo: em primeiro lugar, foi uma limitação de cunho metodológico - para começar a ter algum indício de ação emancipadora realizada pelos professores, eu teria que tê-los acompanhado por um tempo mais longo e tal procedimento foi inviável, dadas as condições nas quais me propus trabalhar. A reflexão compartilhada não deve fazer parte de programas pontuais, mas de projetos e programas estáveis dentro das instituições educacionais. Falo de programas que promovam a instauração de atitudes e práticas reflexivas compartilhadas que se integrem ao fazer profissional diário e constante dos profissionais da Educação; programas contínuos de educação reflexiva, como o de Celani (2003) e sua equipe de pesquisadores, cujas atividades estão sendo desenvolvidas há mais de oito anos. Isso porque o compartilhamento de reflexões sobre as 
nossas ações, para se tornar transformador e emancipador, requer um longo processo de investimento pessoal e profissional, de autoconhecimento e de conhecimento dos outros que conosco trabalham voltados para objetivos comuns que visem à transformação e à emancipação da equipe de profissionais. A segunda limitação de meus dois estudos é de cunho metodológico e contextual. Contextual porque realizei os dois estudos individualmente, sem uma equipe de apoio formada por outros educadores de professores. Esse fato pode até sugerir uma certa onipotência, pois não é possivel implementar e desenvolver um programa de educação reflexiva de professores de modo individual, mas sim por meio de uma equipe, inclusive e se possível interdisciplinar. Não obstante essas duas primeiras limitações, optei por levar adiante os dois estudos devido ao meu interesse nas representações que poderiam trazer (e trouxeram) os professores a respeito de suas práticas e de suas formações profissionais (essas últimas, no caso dos alunos de Letras). Por fim, a terceira limitação que gostaria de apontar é de cunho teórico e metodológico e se fez muito mais clara no estudo francês. Ela diz respeito ao enfoque exclusivo da reflexão realizada somente entre professores, quando esta deveria incluir todos aqueles que participam do processo educativo, em especial o aluno, assim como os pais e os administradores dos estabelecimentos de ensino. Desse ponto de vista de inclusão dos agentes que participam do processo educativo, o estudo realizado no contexto brasileiro por meio do espetáculo teatral foi, portanto, mais completo. Ele incluiu professores, educadores de professores, alunos, pais de alunos, coordenadores de cursos e diretores de escolas que formavam as platéias. Provavelmente seja esta a razão pela qual, após concluir os dois estudos, trago a sensação de que aquele realizado no contexto brasileiro foi mais completo e inclusivo.

Ainda é possível pensar em algumas outras limitações metodológicas que estão ligadas aos procedimentos que tomei e à própria
PEBA. Por exemplo, no estudo realizado no contexto francês, eu sempre estive presente como um estrangeiro. Apesar da disponibilidade e da confiança dos professores franceses em mim depositada, ainda acredito que foi possível ouvir somente parte daquilo que um educador de professores francês ouviria. Esta talvez seja a razão pela qual carrego a impressão de ter ouvido poucos 'danos' com relação à educação francesa, à formação e ao trabalho dos professores franceses. É possível que eles não desejassem abrir totalmente as portas às mazelas do sistema educacional francês aos ouvidos de um estrangeiro. Em compensação, da perspectiva de um observador externo, foi possível acessar e entrever certas peculiaridades da cultura de aprender daquele país, as tensões, frustrações e expectativas dos professores franceses, como quando começaram a refletir acerca dos sistemas de formação inicial, dos estágios e do concurso de entrada na profissão daquele país (o CAPES). Sendo assim, se não tive acesso a certos aspectos das instituições, da vida e da profissão dos professores franceses, da perspectiva de um pesquisador e educador de professores estrangeiro, tive o privilégio de acessar outros dos quais nem os próprios educadores de professores daquele país poderiam ter consciência.

A PEBA se apresenta como um viés fecundo da pesquisa qualitativa, pois oferece possibilidades alternativas às atuais abordagens de educação e reflexão no campo da educação inicial e continuada de professores. Isso porque ela tem condições de viabilizar as intenções dos educadores de professores interessados na promoção de contextos reflexivos como espaços de pesquisa, de revisão e de recriação da prática pedagógica e do conhecimento pessoal e prático que os professores trazem de suas salas de aula. Essa nova modalidade de pesquisa qualitativa viabiliza tais intenções dos educadores de um modo empoderador, já que ela permite e dá condições aos professores de pesquisarem e produzirem os conhecimentos da própria profissão entre os seus colegas e dentro de seus próprios con- 
textos profissionais. Digo empoderador porque tem sido comum o fato de que os professores, as escolas e as salas de aulas sejam repositórios dos resultados das pesquisas realizadas nas universidades. 0 ofício e o fazer dos professores têm sido submetidos constantemente ao escrutínio daqueles alheios à atividade didática das salas de aulas, de especialistas que desejam prescrever o fazer pedagógico aos professores de fora das salas de aulas. Tal prática investigativa é diariamente constatada no ambiente profissional dos professores. Por exemplo, quando um deles atinge um nível de pós-graduação, ele imediatamente se afasta ou é afastado da sala de aula para cumprir algum programa de formação ou qualificação. Uma vez cumpridos esses programas, raramente o docente retorna à sala de aula, mas se dirige à coordenação ou às diretorias de ensino para supervisionar o que é realizado nas escolas - isto é, se posiciona fora da sala de aula. Desse modo, o contato direto entre alunos e professores altamente qualificados é coisa rara. Os professores mais qualificados estão fora da sala de aula, ensinando os outros colegas como ensinar.
Por fim, em meio à situação crítica e caótica das instituições educacionais em todo o mundo, do desprestígio da figura e do trabalho do professor, das crises de apatia e violência espelhadas em nossas salas de aula, a PEBA vem abrir um espaço reflexivo alternativo para que a profissão do professor, sua formação e o seu trabalho nas salas de aula sejam revistos e representados de pontos de vista estéticos, os quais viabilizam desafios e contextos para o compartilhamento das representações de todos aqueles ligados à ação educadora. Desse modo, essa modalidade de pesquisa qualitativa entre docentes instaura uma outra relação entre o professor, seu conhecimento e sua prática, por meio das perspectivas representacionais e de revisitação da vida nas escolas que ela oferece. Desse modo, a importância social e a força revitalizadora dessa nova modalidade de pesquisa se fazem presentes como impulsos de esperança na prática e no desenvolvimento inicial e continuado dos professores, assim como na melhora das práticas sociais e educadoras das escolas brasileiras.

\section{Referências bibliográficas}

ALBA, M. S. Funcionalidad de la simiotica teatral. Anales Del II Simposio Internacional de Semiótica. Universidad de Oviedo, p. 425436, 1988

ANSPACH, S. S. Teatro: domínio da intersemiose. Face Revista de Semiótica e Comunicação, São Paulo, v. 1, n. 2, p. 91-102, 1988.

BARONE, T. The purposes of arts-based educational research. International Journal of Educational Research, v. 23, n. 2, p. 169180, 1995

BARONE, T.; EISNER, E. W. Arts-based educational research. In: JAEGER, R. M. (Ed.). Complementary methods for research in Education. Washington, D.C.: American Educational Research Association, 1997.

BARRIENTOS, J. L. G. Identificacion y distancia: notas sobre la recepcion teatral. Anales Del II Simposio Internacional de Semiótica. Universidad de Oviedo, p.181-196, 1988.

BARTHES, R. A câmera clara. Rio de Janeiro: Nova Fronteira, 1984.

BOAL, A. Teatro do oprimido (e outras poéticas políticas). São Paulo: Civilização Brasileira, 1991. 
0 teatro como arte marcial. Rio de Janeiro: Garamond, 2003.

BOCHNER, A. P.; ELLIS, C. An introduction to the arts and narrative inquiries: arts as inquiry. Qualitative Inquiry, v. 9, p. 506-514, 2003.

BRESLER, L. (Ed.). Knowing bodies, moving minds: towards embodied teaching and learning. London: Kluwer Academic Publishers, 2004.

BULLOUGH, R. V.; STOKES, D. K. Analysing personal teaching metaphors in preservice teacher education as a means for encouraging professional development. American Educational Research Journal, v. 31, n. 1, p. 197-224, 1994.

CARROLL, N. Visual metaphor. In: HINTIKKA, J. Aspects of metaphor. Dordrecht, The Netherlands: Marinus Nijhoff Publishers, 1994.

CELANI, M. A. A. Professores formadores em mudança: relato de um processo de reflexão e transformação da prática docente. Campinas: Mercado das Letras, 2003.

CLANDININ, D. J.; CONNELLY, M. F. Teachers' professional knowledge landscapes. New York: Teachers' College Press, 1995.

. Narrative inquiry: experience and story in qualitative research. San Francisco: Jossey-Bass Publishers, 2000.

COURTNEY, R. The quest: research and inquiry in arts education. Lanham, MD: University Press of America, 1987.

DAMIANOVIC, M. C. C. C. L. Caminhando, buscando e tecendo significados de vida e educação. Dissertação (Mestrado em Lingüística Aplicada e Estudos da Linguagem) - Pontifícia Universidade Católica-SP, 1998.

DENZIN, N. K. The many faces of emotionality. In: ELLIS, C.; FLAHERTY, M. G. (Eds.). Investigating subjectivity. Newbury Park, CA: Sage Publications, 1992.

DEWEY, J. A arte como experiência. São Paulo: Abril, 1934/1974.

DIAMOND, C. T. P.; MULLEN, C. A. The postmodern educator: arts-based inquiries and teacher development. New York: Peter Lang, 1999 .

DIAS, L. C. F. A construção da(s) subjetividade(s) de professoras de línguas estrangeiras: histórias de professores, discursos e reflexão crítica. Dissertação (Mestrado) - Universidade Estadual Paulista, Campus de Assis, 2001.

DOISNEAU, R. Les doigts pleins d'encre. Paris: Editions Hoëbeke, 1989.

EISNER, E. W. The enlightened eye. New York: Macmillan Publishing Company, 1991.

The promise and perils of alternative forms of data representation. Educational Researcher, v. 26, n. 6, p. 4-10, 1997.

FAIRCLOUGH, N. Language awareness. London: Longman Group, 1992.

FÉRAL, J. La théâtralité: recherche sur la spécificité du langage teatral. Poetique, v. 75, p. 347-361, 1988.

FORDON, A. E. Arts-based educational studies: an "adventurous option to arts-based educational research. Disponível em: <http://www.findarticles.com/p/articles/mi_qa3971/is_200007/ai_n8911881/print> Acesso em: 2005.

GRAY, R. E. Performing on and off the stage: the place(s) of performance in arts-based approaches to qualitative inquiry. Qualitative Inquiry, v. 9, n. 2, p. 254-267, 2003.

GREENE, M. Texts and margins. Harvard Educational Review, v. 61, n. 1, p. 27-39, 1991.

Releasing the imagination: essays on education, the arts, and social change. San Francisco: Jossey-Bass Publishers, 1995.

Variations on a blue guitar: the Lincoln Center Institute lectures on aesthetic education. New York: Teachers College Press, 2001.

LAKOFF, G.; JOHNSON, M. Metaphors we live by. Chicago: University of Chicago Press, 1980. 
LUCERO, J. J. Apuntes para una interacción de la experiencia estética desde su carácter postmoderno. Dispersión: Revista Electrônica del Instituto de Psicologia y Desarrollo, v. 2, n. 6, p. 1-9, 2005.

MELO, D. M. Viajando por um ser chamado professor. Dissertação (Mestrado em Lingüística Aplicada e Estudos da Linguagem) - Pontifícia Universidade Católica-SP, 1999.

MEZIROW, J. (Ed.). Fostering critical reflexion in adulthood. San Francisco: Jossey-Bass Publishers, 1991.

MOTTA, L. M. V. M. Reflexão e conscientização para o uso de estratégias de aprendizagem: dois momentos no desenvolvimento do professor. Dissertação (Mestrado em Lingüística Aplicada e Estudos da Linguagem) - Pontifícia Universidade Católica-SP, 1997.

MUNBY, H. Metaphors in the thinking of teachers: an exploratory study. Journal of Curriculum Studies, v. 18, n. 2, p.197-209, 1986.

PIMENTA, S. G.; GHEDIN, E. Professor reflexivo no Brasil: gênese e crítica de um conceito. São Paulo: Cortez, 2002.

PIRES, E. A. De mapas e posturas críticas: histórias das reflexões entre uma professora e sua coordenadora. Dissertação (Mestrado em Lingüística Aplicada e Estudos da Linguagem) - Pontifícia Universidade Católica-SP,1998.

ROLNIK, S. Memorial e currículum vitae: concurso para ascensão na carreira para professor titular. Pontifícia Católica de São Paulo, Departamento de Psicologia Social, 7 de maio de 1993.

A cafetinagem da criação. Folha de São Paulo, São Paulo, p. 03, 2 de fevereiro, 2003.

SALDAÑA, J. Dramatizing data. Qualitative Inquiry, v. 9, n. 2, p. 218-236, 2003.

SANTAGADA, M. A. La recepcion teatral entre la experiencia estetica y la accion ritual. Tese (Doctorat sur mesure em theatrologie) - Université Laval, 2004.

SARASON, S. B. Teaching as a performing art. New York: Teachers College Press, 1999.

SCHÖN, D. A. The reflective practitioner. New York: Basic Books, 1983.

Educating the reflective practitioner. San Francisco: Jossey-Bass Publishers, 1987.

The reflective turn. New York: Teachers College Press, 1991.

SLATTERY, P. Postmodern curriculum research and alternative forms of data representation. Paper presented to the Curriculum and Pedagogy Institute of the University of Alberta, 29 September, 1997.

SPOLIN, V. Improvisation for the theater. Evanston, Illinois: Northwestern University Press, 1976.

TELLES, J. A. Metaphors as coalescences of teachers' beliefs of language, their students and language teaching. Letras, v. 16, n. 1, p. 86-115, 1997.

Brincando com Rosa: uma professora busca o valor da palavra. Videobiografia. Videoteca da Secretaria Municipal da Educação de São Paulo, 1998a.

. Lying under the mango tree: Autobiography, teacher knowledge and awareness of self, language and pedagogy. The ESPecialist, v. 19, n. 2, p. 185-214, 1998b.

. Educação de professores: espaço, sentimento e prazer. Videobiografia. Videoteca da Secretaria Municipal da Educação de São Paulo, 1998c.

. A trajetória narrativa: histórias sobre a formação do professor de línguas e sua prática pedagógica. Trabalhos em Lingüística Aplicada, v. 34, p. 79-92, 1999.

. Biographical connections: experiences as sources of legitimate knowledge. International Journal of Qualitative Studies in Education, v. 13, n. 3, p. 251-262, 2000. 
Modos de representação: 0 espetáculo teatral como dispositivo de reflexão e representação do desenvolvimento do professor. In: ABRAHÃO, M. H. V. (Org.). Prática de ensino de língua estrangeira: experiências e reflexões. Campinas: Pontes Editores, 2004.

Pesquisa educacional com base nas artes e reflexão compartilhada: por formas alternativas de representação da docência e do conhecimento dos professores. Tese (Livre-Docência)- Universidade Estadual Paulista, Faculdade de Ciências e Letras, 2005.

VALADARES, J. M. 0 professor diante do espelho: reflexões sobre o conceito de professor reflexivo. In: PIMENTA, S. G.; GHEDIN, E. (Orgs.). Professor reflexivo no Brasil: gênese e crítica de um conceito. São Paulo: Cortez, 2002.

Recebido em 26.08.05

Modificado em 13.03.06

Aprovado em 26.06.06

João A. Telles é professor livre-docente no Departamento de Educação, UNESP-Assis e atua nos Programas de PósGraduação em Educação da UNESP-Marília e em Estudos Lingüísticos, UNESP-S.J. do Rio Preto. Doutor em Lingüística Educacional pelo OISE - Ontário Institute for Studies in Education, Universidade de Toronto, Canadá. Pós-doutorado pela Universidade Charles-de-Gaulle, Lille III, França e Mestre em Lingüística Aplicada pela PUC-SP. 